\title{
Playing Bluntschli
}

\author{
RALPH RICHARDSON
}

From Hal Burton, ed., Great Acting (London: British Broadcasting Corporation, 1967; New York: Hill \& Wang, 1968) p. 68. Sir Ralph David Richardson (190283) played the part of Bluntschli in the Old Vic 1930-1 production of Arms and the Man. Another Shavian role played by Richardson was that of William the Waiter in You Never Can Tell, at the Haymarket Theatre in 1966.

Shaw came a good deal to rehearsal and he helped me very much indeed. As you remember, when Bluntschli comes on at the beginning of the play, he has escaped from the enemy, and climbed up a drainpipe and in through a window in a terrible state of exhaustion. I tried to act the exhaustion and to show how utterly tired and shot to hell he was. We rehearsed this for a time, and I thought it was rather a good effect, and that I was rather good in it. Then Shaw came to me and he said, 'You know, Richardson, I'd like to have a word with you about your Bluntschli. It's going to be a very fine Bluntschli, I'm sure.' He was a wonderfully courteous, wonderfully polite man, I think perhaps the most polite man I've ever met in my life, especially sensitive to actors. You know, he'd take you aside and talk to you very quietly, very gently, very encouragingly. 'But,' he said, 'you know there's one thing the matter with your Bluntschli. When you come in, you show that you're very upset, you spend a long time with your gasps and your pauses and your lack of breath and your dizziness and your tiredness; it's very well done, it's very well done indeed, but it doesn't suit my play. It's no good for me, it's no good for Bernard Shaw.' He said, 'You've got to go from line to line, quickly and swiftly, never stop the flow of the lines, never stop. It's one joke after another, it's a firecracker. Always reserve the acting for underneath the spoken word. It's a musical play, a knockabout musical comedy.' That taught me a lot about playing in his plays. 